\title{
Relationship Between Organizational Culture, Employee Satisfaction and Organizational Commitment
}

\author{
Sarantuya Jigjiddorj ${ }^{1, *}$, Altanchimeg Zanabazar ${ }^{1}$, Tsolmon Jambal $^{2}$, Buyankhishig Semjid ${ }^{3}$ \\ ${ }^{1}$ National University of Mongolia, Business School, Management Department, Mongolia \\ ${ }^{2}$ Institute of Technology and Business, Faculty of Corporate Strategy, Department of Management, Nemanická 536/7, 370 01 Česke \\ Budejovice, Czech Republic \\ ${ }^{3}$ National University of Mongolia, Business School, Management Department, Mongolia
}

\begin{abstract}
Organizational culture is an important human resource management issue that affects the success and sustainability of a company. In organizational settings, culture describes what is unique about an organization, as expressed by the shared beliefs and values established by the founders and communicated through different ways. This shapes employees' perceptions and behaviour, as well as the principles that apply to members of an organization.

Job satisfaction refers to an employee's feelings about their job and is frequently studied in relation to organizational culture and other variables, such as job commitment, performance and organizational commitment.

Organizational commitment refers to whether an employee wishes to continue working for an organization or leave it. Employees tend to be attracted to those organizations with a culture that values their work and focuses on organizational wellbeing. There is a positive relationship between organizational culture, job satisfaction and the organizational commitment of employees.
\end{abstract}

Keywords: Organizational culture; job satisfaction; organizational commitment; case study

\section{Introduction}

An organization is a group of people united by common goals, with an open system that adapts to the ever changing external environment. Regardless of company size and the industry they operate in, organizations embrace three elementsgoals, people and systems. People interact within a system, thereby contributing to the achievement of an organization's goals. Every organization embraces its own culture, which includes its goals, values and interactions with the external environment. What makes an organization's culture unique are the feelings, beliefs, standards, customs and rules that it is based on.

By nurturing a strong positive organizational culture, employees become more committed and responsible. It unites the ambitions of employees to become goal oriented. If an organization has loyal and committed employees, this may be a sign of job satisfaction, which is essential for achieving an organization's goals.

\section{Background}

Organizational culture is an important topic for researchers and practitioners of human resource management. In organizational settings, culture describes what is unique about an organization, as expressed by the shared beliefs and values established by the founders and communicated through different ways. This shapes employees' perceptions and behaviour, as well as the principles that apply to members of an organization. The majority of researchers agree that organizational culture is a system of shared values, beliefs and behaviours of members of an organization [1].

According to the Schein [2], organizational culture can be observed in three forms, namely a) observable artefacts specific attitudes, beliefs, values and other features like dress code, stories, rituals and special ceremonies that are specific to an organization; b) supported values - values widely promoted by the leaders and which are very likely reflected in the behaviour of employees. These values generally guide the behaviour of members of an organization in different situations; and c) basic assumptions or perceived situations - these regulate the collective actions of the members, which are the result of long-term practice and are valued by every organizational member, who practices them instinctively. In doing so, a sense of belonging to a community is generated.

\footnotetext{
*Corresponding author: sarantuyaj@num.edu.mn
} 
Numerous studies have been conducted into types of organizational cultures, thereby referring to their format and functions [3], environmental requirements [4], and models [5] based on employee relations. They identified four completely different cultures, namely hierarchical, market, clan and adhocracy. Other researchers identified the existence of sub-cultures within an organization [6] based on individualistic and collective cultures related to employees' social groupings. Beyond this, organizational culture has also been studied in relation to workplace related issues, such as wellbeing or quality of work life. This concerns an organization's ability to promote and maintain the physical, psychological and social wellbeing of employees at all levels and for all jobs [7]. This includes the employees' physical and mental health, sense of happiness and social wellbeing, which are recognized in the term job satisfaction [8].

A widely studied topic closely linked to organizational culture is that of job satisfaction. Job satisfaction refers to an employee's feelings about their job and is frequently studied in relation to organizational culture and other variables, such as job commitment, performance and organizational commitment. Job satisfaction is an important issue for all organizations because it is a crucial factor for organizational success and sustainability [9]. According to Lund [10], if job satisfaction is high, this reflects a strong organizational culture, and vice versa, if job satisfaction is low, the organizational culture is weak. Other studies show that satisfied employees tend to be more productive, creative and committed to their employers. According to [11], job satisfaction leads to higher productivity through greater motivation and the enhancement of the working capabilities of employees.

Barbara and Dormio [12] conducted research into the effect of organizational culture on job satisfaction. They showed that organizational culture had a positive effect on job satisfaction. The research conducted by Nayak and Barik [13] produced a similar result. Moreover, Park \& Kim [14], Cronley \& Kim [15] and Belias \& Koustelios [16] conducted comprehensive studies into organizational culture and related variables, all of which also confirmed that organizational culture has a positive influence on job satisfaction.

Another widely observed and often researched topic is that of the relationship between organizational culture and organizational commitment. Organizational commitment refers to an individual's psychological attachment to the organization they work for. The relationship between organizational culture and organizational commitment is theoretically described by Peters and Waterman [17]. They suggest that organizational culture influences a variety of organizational and individual outcomes including productivity, performance, commitment and self-confidence.

Organizational culture is considered to have a strong relationship to organizational commitment. This is reflected in how members of an organization follow the provisions made by an organization. If an organization is well-organized, whereby the leader takes their authority and responsibility seriously, then its members will certainly be committed to the organization [18]. Another study suggests that organizational culture in the form of good communication, trust and an innovative culture, positively influences organizational commitment [19].

Organizational cultures characterized as being collaborative, a brotherhood, participatory, consensual, constructive and supportive are more likely to benefit from higher levels of organizational commitment. Abdullah, Shamsuddin and Wahab [20] showed this to be true. Organizational culture has also been studied in relation to different variables, such as leadership and employee performance [21], and the impact of it on leadership style, organizational commitment and its relationship to job satisfaction [22].

\subsection{Problem statement}

Numerous studies have previously been conducted on the relationship between organizational culture, job satisfaction and employee commitment in universities in Pakistan [23]. Denisten, Sarros and Gray [24] attempted measuring the levels of employee satisfaction in organizational cultures against the job satisfaction of marketing staff. Similar research was conducted in the fertilizer industry in Pakistan. These attempts to measure the correlation between organizational culture, job satisfaction and organizational commitment serve as examples for extending the research on the selected topic.

When taking onto consideration past research and the opportunities to apply such concepts to the analysis of the current state of affairs within a local context, the following problems statements were formulated:

- The examined organizational culture has an impact on job satisfaction;

- The examined organizational culture has an impact on organizational commitment.

\subsection{Scope of the study}

The purpose of the study presented here is to explore the impact of the organizational culture of an insurance company on the job satisfaction and organizational commitment of its employees. The study's aims are, based on the results of an analysis, to enhance human resource management practices, including potential changes to the workplace environment, to improve job satisfaction and organizational commitment.

Research design: Based on previous studies, the following research model was developed to achieve the proposed aims of the study 


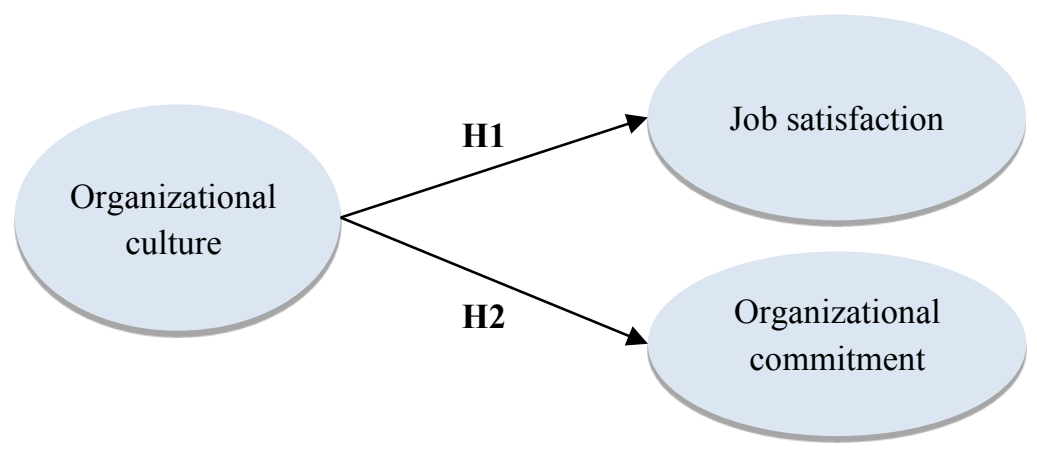

Figure 1. Research model

Source: Authors.

\section{Research hypotheses:}

H1: Organizational culture has an impact on job satisfaction.

$\mathrm{H} 2$ : Organizational culture has an impact on organizational commitment

\section{Methodology}

The beneficiary of the conducted socio-metric survey and analysis is a major insurance company operating in the local market. SPSS 23 software was used for the data analysis. Reliability tests, and correlation and regression analyses were conducted to determine the relationship between the independent and dependent variables.

The survey was conducted between $4^{\text {th }}$ and $20^{\text {th }}$ November 2019 . Out of the 180 questionnaires distributed to employees, 152 were returned (a response rate of 84.4\%). After cleaning the data, it was determined that the data from 151 questionnaires could be used for the analysis.

The questionnaire consisted of 61 questions, each with a 5-point Likert scale, grouped into 3 categories. The background data of the respondents is summarized in Table 1.

Table 1. Background of the respondents

\begin{tabular}{|c|c|c|c|c|c|c|c|}
\hline \multicolumn{2}{|c|}{ Gender } & \multicolumn{2}{|c|}{ Age level } & \multicolumn{2}{|c|}{ Education background } & \multicolumn{2}{|c|}{$\begin{array}{c}\text { Years of service in current } \\
\text { position }\end{array}$} \\
\hline Gender & $\%$ & $\begin{array}{c}\text { Age } \\
\text { (in yrs) }\end{array}$ & $\%$ & Education level & $\%$ & Tenure & $\%$ \\
\hline \multirow{3}{*}{ Male } & \multirow{3}{*}{35.8} & $\leq 20$ & 0.7 & \multirow{2}{*}{ Master's degree } & \multirow{2}{*}{15.9} & $\leq 1$ year & 31.8 \\
\hline & & $21-25$ & 7.3 & & & $1-3$ years & 23.3 \\
\hline & & $26-30$ & 24.5 & Undergraduate degree & 76.8 & 4-10 years & 33.1 \\
\hline \multirow{4}{*}{ Female } & \multirow{4}{*}{64.2} & $31-35$ & 25.8 & \multirow{2}{*}{ Professional education } & \multirow{2}{*}{4.6} & $11-15$ years & 3.3 \\
\hline & & $36-40$ & 15.9 & & & $16-20$ years & 4.6 \\
\hline & & $41-50$ & 12.6 & \multirow{2}{*}{$\begin{array}{l}\text { Incomplete secondary } \\
\text { education }\end{array}$} & \multirow{2}{*}{1.3} & \multirow{2}{*}{$>21$ years } & \multirow{2}{*}{3.3} \\
\hline & & $>55$ & 11.3 & & & & \\
\hline
\end{tabular}

Source: Authors.

By demographics: $64.2 \%$ of the respondents were female; $58.3 \%$ were younger than 35 years old; and $55.1 \%$ had worked in their current positions for up to 3 years.

By the positions held by the respondents: $68.2 \%$ were employees; $9.9 \%$ senior executives; and the remaining $16.6 \%$ were department or branch managers (see Figure 2). 


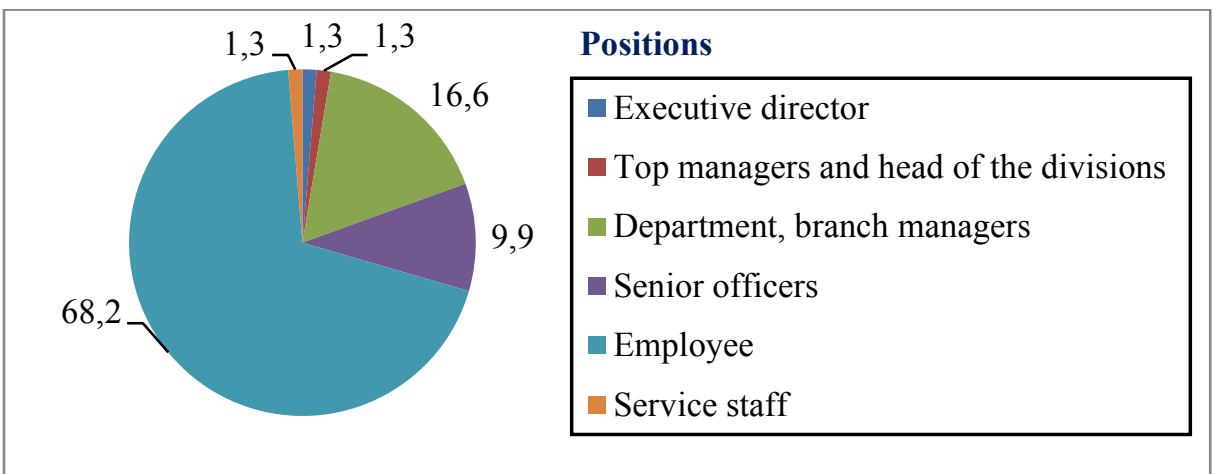

Figure 2. Positions held by the respondents

Source: Authors.

\subsection{Sample size}

To ensure the adequacy of the sampling, Kaiser-Meyer-Olkin (KMO) and Bartlett's tests were performed. In general, the higher the KMO value, the greater the adequacy of the sample size and the less likely remedial measures need to be taken. The significance test (Sig.) checks the variances across samples. A KMO value less than 0.5 indicates that the sample size is inadequate. The results of the Kaiser-Meyer-Olkin (KMO) and Bartlett's tests are summarized in Table 2.

Table 2. Summary of sampling adequacy tests

\begin{tabular}{|c|c|c|}
\hline \multicolumn{3}{|c|}{ KMO and Bartlett's tests } \\
\hline \multirow{2}{*}{ Kaiser-Meyer-Olkin measure of sampling adequacy } & 0.725 \\
\hline \multirow{3}{*}{ Bartlett's test of sphericity } & Approx. Chi-Square & 17293.155 \\
\cline { 2 - 3 } & $\mathrm{df}$ & 6328 \\
\cline { 2 - 3 } & Sig. & .000 \\
\hline
\end{tabular}

Source: Authors.

According to the test results, the KMO value is 0.725 , which means that the sample size is adequate. The significance value $($ Sig. $=0.000)$ of Bartlett's test of sphericity means that the variances across the samples are equal and that the data are reliable for conducting further analysis.

\subsection{Reliability analysis of variable}

Data reliability was tested to ensure the consistency of the set of variables. For the measurement of the closeness, or scale reliability of the related set of items, Cronbach $\alpha$ was estimated. According to Nunnally [25], a Cronbach $\alpha$ value of 0.7 is an acceptable value for measurement. On the basis of the results (see Table 3), it can therefore be said that the design of the developed questionnaire was appropriate for the purpose of the survey, which was found to be capable of measuring the proposed issues. The results of the test are summarized in the table below.

Table 3. Reliability test results

\begin{tabular}{|l|c|c|}
\hline Set of items & $\begin{array}{c}\text { Number of } \\
\text { questions }\end{array}$ & Cronbach's $\boldsymbol{\alpha}$ \\
\hline Organizational culture & 15 & .912 \\
\hline Organizational commitment & 15 & .843 \\
\hline Job satisfaction & 34 & .969 \\
\hline
\end{tabular}

Source: Authors.

\subsection{Correlation analysis}

The results of the correlation analysis are summarized in Table 4. 
Table 4. Correlation Analysis

\begin{tabular}{|c|c|c|c|c|c|}
\hline \multicolumn{6}{|c|}{ Correlations } \\
\hline & & $\mathrm{OC}$ & OCOM & $\mathrm{JS}$ & \\
\hline $\mathrm{OC}$ & $\begin{array}{l}\text { Pearson correlation } \\
\text { Sig. (2-tailed) } \\
\text { N }\end{array}$ & 1 & & & \\
\hline OCOM & $\begin{array}{l}\text { Pearson correlation } \\
\text { Sig. (2-tailed) } \\
\text { N }\end{array}$ & $\begin{array}{r}.558^{* *} \\
.000 \\
151 \\
\end{array}$ & 1 & & \\
\hline JS & $\begin{array}{l}\text { Pearson correlation } \\
\text { Sig. (2-tailed) } \\
\mathrm{N}\end{array}$ & $\begin{array}{r}.718^{* *} \\
.000 \\
151 \\
\end{array}$ & $\begin{array}{r}.450^{* *} \\
.000 \\
151 \\
\end{array}$ & & 1 \\
\hline
\end{tabular}

** correlation is significant at the 0.01 level (2-tailed).

Source: Authors.

Although the correlation between organizational culture $[\mathrm{r}=.718 ; \mathrm{N}=151 ; \mathrm{p}<0.01]$ and job satisfaction $[\mathrm{r}=.522 ; \mathrm{N}=405$; $\mathrm{p}<0.01]$ is strong, the correlation with organizational commitment $[\mathrm{r}=.558, \mathrm{~N}=151, \mathrm{p}<0.01]$ is only slightly positive.

\subsection{Regression analysis}

To test the hypotheses of the study, regression analyses were performed, the results of which are presented in Table 5.

Table 5. Regression analysis

Model summary

\begin{tabular}{|c|c|c|c|c|}
\hline Model & $\mathrm{R}$ & R Square & $\begin{array}{c}\text { Adjusted R } \\
\text { Square }\end{array}$ & $\begin{array}{c}\text { Std. error of the } \\
\text { estimate }\end{array}$ \\
\hline 1 & $.718 \mathrm{a}$ & .515 & .512 & 11.6222 \\
\hline 2 & $.558^{\mathrm{a}}$ & .311 & .306 & 2.762 \\
\hline
\end{tabular}

a. Predictors: (Constant), OC

Source: Authors.

ANOVA $^{\mathrm{a}}$

\begin{tabular}{|c|l|c|r|r|r|c|}
\hline \multicolumn{2}{|c|}{ Model } & Sum of Squares & df & Mean Square & F & Sig. \\
\hline \multirow{2}{*}{1} & Regression & 49181.427 & 1 & 49181.427 & 158.373 & $.000^{\mathrm{b}}$ \\
& Residual & 46270.745 & 149 & 310.542 & & \\
& Total & 95452.172 & 150 & & & \\
\hline \multirow{2}{*}{2} & Regression & 512.738 & 1 & 512.738 & 67.235 & $.000^{\mathrm{b}}$ \\
& Residual & 1136.282 & 149 & 7.626 & & \\
& Total & 1649.020 & 150 & & & \\
\hline
\end{tabular}

a. Dependent variable: JS, OCOM

b. Predictors: (Constant), OC

Source: Authors.

Coefficients $^{\mathbf{a}}$

\begin{tabular}{|c|c|c|c|c|c|c|}
\hline & \multirow{2}{*}{ Model } & \multicolumn{2}{|c|}{ Unstandardized coefficients } & $\begin{array}{c}\text { Standardized } \\
\text { coefficients }\end{array}$ & \multirow{2}{*}{$\mathrm{t}$} & \multirow{2}{*}{ Sig. } \\
\hline & & $\mathrm{B}$ & Std. Error & Beta & & \\
\hline 1 & JS & .944 & .154 & .718 & 12.585 & .000 \\
\hline 2 & OCOM & .199 & .024 & .558 & 8.200 & .000 \\
\hline
\end{tabular}

a. Dependent variable: JS, OCOM

Source: Authors. 
According to the test results, there is a positive correlation between organizational culture and job satisfaction $(51.2 \%$; $\mathrm{R}$ Square $=.512)$ and a slightly positive one with organizational commitment $(30.6 \%$; R Square $=.306)$. In the case of the surveyed organization, the organizational culture of the organization has a positive impact on the job satisfaction of its employees. An increase of one unit in organizational culture results in $\beta=.718$, or in other words, an increase in job satisfaction $[\beta=.718 ; p<0.01]$. However, the results also show that organizational culture has only a slightly positive correlation with organizational commitment. Clearly, an increase of one unit in organizational culture only increases organizational commitment by $\beta=0.558$ unit or $[\beta=.558, \mathrm{p}<0.01]$.

The aforementioned results are graphically presented in Figure 3.

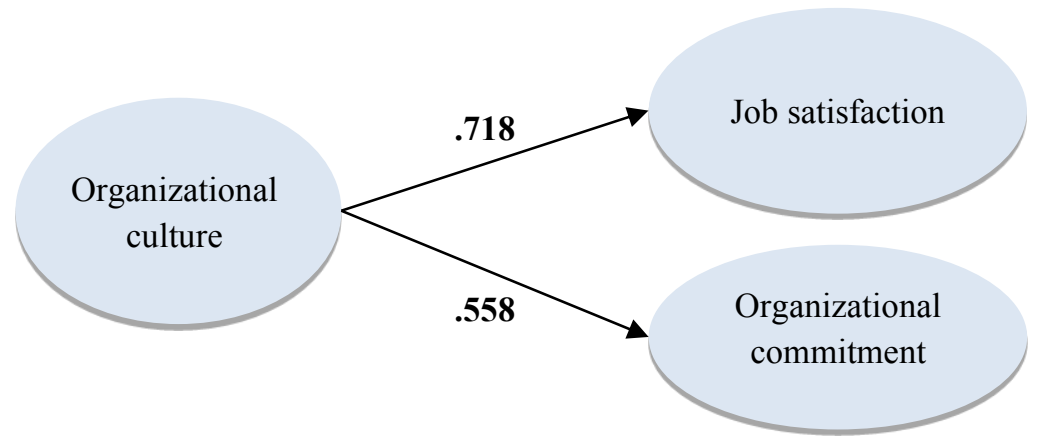

Figure 3. Results of the study

Source: Authors.

The strength of the independent variable in relation to the dependent variables shows a positive effect (high Beta coefficient value) and demonstrates strong statistical significance $(\mathrm{p}<0.01)$. This enables us to confirm both hypotheses.

As was the case in other studies [23], the survey results demonstrate that there is a strong correlation between organizational culture and job satisfaction, and less so to organizational commitment. It should be noted that there is room for improvement, such as covering different industry representatives and including more respondents, in order to better observe the correlation between organizational culture and organizational commitment.

\section{Conclusion}

Organizational culture is a strong variable that ensures the long-term sustainability of an organization by enabling it to distinguish itself from its competitors. Organizations with a strong culture are better able to retain committed employees who feel satisfied about their jobs, which reduces staff turnover.

Job satisfaction is a challenging issue for the management of any organization. Through organizational culture, it is possible to increase job satisfaction, which in turn can nurture an employee's commitment and willingness to stay for a longer period of time.

The presented study was based on the evidence of similar previous studies conducted in different countries among diverse communities into the relationship between organizational culture and job satisfaction, and organizational culture and organizational commitment. The principles applied in those earlier studies were applied to a local case, namely a local insurance company. The survey results showed that there is a positive relationship between the selected variables, thereby confirming the results of the previous studies.

According to our study, an increase in the strength of organizational culture by one unit, leads to an increase in job satisfaction. Similarly, an increase in the strength of organizational culture by one unit leads to an increase in organizational commitment $(\beta=0.558$ unit), although to a lesser degree than the former.

We can conclude that organizational culture has a strong impact on employee job satisfaction and less so on organizational commitment.

On the assumption that the principles of the presented study are valuable and reliable, it may be useful to add more dependent variables in relation to organizational culture in order to improve human resources management within an organization and to encourage people to become more goal oriented and committed to achieving organizational goals.

\section{References}

1. D. Ravasi, M. Schultz, Responding to Organizational Identity Threats: Exploring the Role of Organizational Culture. Academy of Management Journal. 49(3), 433-458 (2006)

2. E. H. Schein, Organizational culture and Leadership. $3^{\text {rd }}$ ed. San Francisco: Jossey-Bass (2004) 
3. T. Deal, A. Kennedy, Corporate Cultures: The Rites and Rituals of Corporate Life. Boston: Addison-Wesley Publishing (1982)

4. R. Daft, Essentials of Organization Theory \& Design. Cincinnati: South-Western College Publishing (2001)

5. K. S. Cameron, R. E. Quinn, Diagnosing and Changing Organizational Culture Based on the Competing Values Framework. The Jossey-Bass Business \& Management Series. San Francisco: Jossey-Bass, A Wiley Imprint (2006)

6. D. Denison, C. Lief, J. L. Ward, Culture in Family-Owned Enterprises: Recognizing and Leveraging Unique Strengths. Family Business Review. 17(1), 61-70 (2004)

7. P. Torri, E. Toniolo, Organizational well being: Challenge and future foundation. Giornale italiano di medicina del lavoro ed ergonomia. 32(3), 363-367 (2010)

8. A. M. Grant, M. K. Christianson, R. H. Price, Happiness, Health, or Relationships? Managerial Practices and Employee Well-Being Tradeoffs. Academy of management perspectives. 21(3), 51-63 (2007)

9. S. P. Robbins, T. A. Judge, Organisational Behavior. $15^{\text {th }}$ ed. Boston: Pearson (2013)

10. D. Lund, Organizational culture and job satisfaction. Journal of Business \& Industrial Marketing. 18(3), 219-236 (2003)

11. K. Bhatti, T. Qureshi, Impact of employee participation on job satisfaction, employee commitment and employee productivity. International Review of Business Research Papers. 3(2), 54-68 (2007)

12. B. Bigliardi, A. I. Dormio, F. Galati, G. Schiuma, The impact of organizational culture on the job satisfaction of knowledge workers. VINE. 42(1), 36-51 (2012)

13. B. Nayak, A. Barik, Assessment of the link between Organizational culture and job satisfaction (Study of an Indian Public Sector). International Journal of Advanced System and Social Engineering Research. 13(3), 78-87 (2013)

14. J. S. Park, T. H. Kim, Do types of organizational culture matter in nurse job satisfaction and turnover intention? Leadership in Health Services. 22(1), 20-38 (2009)

15. C. Cronley, Y. K. Kim, Intentions to turnover: Testing the moderated effects of organizational culture, as mediated by job satisfaction, within the Salvation Army. Leadership and Organization Development Journal. 38(2), 194-209 (2017)

16. D. Belias, A. Koustelios, Organizational Culture and Job Satisfaction: A Review. International Review of Management and Marketing. 4(2), 132-149 (2014)

17. T. J. Peters, R. H. Waterman, In Search of Excellence: Lessons from America's Best-run Companies, Reprint edition. New York: Harper Business (2006)

18. T. Lim, Relationships among Organizational Commitment, Job Satisfaction, and Learning Organization Culture in one Korean Private Organization. Asia Pacific Education Review. 11(3), 311-320 (2003)

19. M. Muliaty, M. Basri, J. Jasruddin, Effects of organizational transformation and culture on employees performance. International Journal of Economic Perspectives. 11(3), 1287-1292 (2017)

20. N. H. Abdullah, A. Shamsuddin, E. Wahab, Does organizational culture mediate the relationship between transformational leadership and organizational commitment? International Journal of Organizational Leadership. 4, 18-32 (2015)

21. A. Xenukou, M. Simosi, Organizational culture and transformational leadeship as predictors of buisness unit performance. Journal of Managerial Psychology. 21(6), 566-579 (2006)

22. L. H. Yiing, K. B. Ahmad, The moderating effects of organizational culture on the relationships between leadership behavior and organizational commitment and between organizational commitment and job satisfaction and performance. Leadership and Organizational Develoment. 30(1), 53-86 (2009)

23. M. R. Awan, K. Mahmood, Relationship among leadership style, organizational culture and employee commitment in university libraries. Library Management Journal. 31(4), 253-266 (2010)

24. I. L. Densten, J. C. Sarros, J. Gray, Leadership and its impact on organizational culture. International journal of business studies. 10(2), 1-26 (2002) 
25. J. C. Nunnally, Psychometric Theory. New York: McGraw-Hill (1978) 